\title{
Impact of Vermicompost Tea and Tagetes erecta Extract to Control Onion Purple Blotch Disease
}

\section{Amin, M.M.}

\author{
Plant Pathology Research Institute, Agricultural Research \\ Center, Giza, Egypt.
}

V ermicompost tea (VCT) and extract of Tagetes erecta L. (TE) were used to study their effect on onion purple blotch caused by Alternaria porri (Ellis) Cif, under laboratory and field conditions in comparison with the recommended fungicide Luna Experience. In vitro, efficacy of TE extract at $0.25,0.50,1.0,2.0$ and $3.0 \mathrm{ml} / \mathrm{L}$ PDA medium on linear growth of $A$. porri was estimated. The inhibitory effect of TE on $A$. porri was increased by increasing the TE concentrations, as the $3 \mathrm{ml} / \mathrm{L}$ caused $51.3 \%$ growth reduction. Under field conditions, at Etay El-Baroud Agricultural Research Station, Beheira governorate, Egypt, seven sprays with VCT at 12.5 and 25 $\mathrm{ml} / \mathrm{L}$ and TE at 2 and $3 \mathrm{ml} / \mathrm{L}$ were used on Italy red and Giza $20 \mathrm{cvs}$. onion plants during 2015/2016 and 2016/2017 growing seasons to evaluate their effect on disease severity, no. of leaves, plant height, onion bulb yield, chlorophyll $\mathrm{a}$ and $\mathrm{b}$ content and activity of peroxidase and polyphenoloxidase enzymes. TE extract at $3 \mathrm{ml} / \mathrm{L}$ was the most effective comparing with VCT and Luna Experience to reduce purple blotch severity with efficacy of 66.2 and $72.5 \%$ on Italy red and Giza 20 plants, respectively. Leaves number, plant height and onion bulb yield were increased positively with treatment concentrations. VCT at the rate of $25 \mathrm{ml} / \mathrm{L}$ gave $49.6,50.4 \mathrm{~kg} / \mathrm{plot}$ for cv. Italy red and 47.9, $47.3 \mathrm{~kg} / \mathrm{plot}$ for cv. Giza 20 as the best tested treatment to increase onion bulb yield in the two successive seasons. All treatments increased contents of chlorophyll $\mathrm{a}$ and $\mathrm{b}$ and activity of peroxidase and polyphenoloxidase in onion plant leaves.

Keywords: Alternaria porri, onion purple blotch, Tagetes erecta and vermicompost.

Onion (Allium cepa L.) is one of the oldest known and most important field crops grown all over the world. In Egypt, onion is used for local consumption in different ways, exportation and also as a medicinal plant. Foliar, bulbs and root diseases are of the most important factors causing low productivity of onion yield and quality (Cramer, 2000). Purple blotch caused by Alternaria porri (Ellis) Cif is one of the most destructive common diseases prevailing in almost all onion growing areas of the world. Losses mainly result from reduced bulb size and poor storage quality (Surviliene et al., 2008). The disease is more severe on onion seed yield than on bulb yield, where it sometimes causes $100 \%$ loss of onion seed production (AbdelRahim et al., 2016). Vermicompost is a low-cost technology for processing organic 
waste through interactions between earthworms and microorganisms (Hand et al., 1988 and Edwards and Arancon, 2004). Vermicompost aqueous extracts could be aerated or non-aerated and much easier to handle and apply than solid compost (Yardim et al., 2006). Vermicompost tea was recommended to be applied as foliar spray or soil drench to improve plant health, yield and nutritive quality (Ingham, 2005). The genus Tagetes is a native to Americas but some of its members, in particular $T$. erecta L. and $T$. patula L. commonly known as marigolds were naturalized in the old world, i.e., India, North Africa, and Europe (Nahak and Sahu, 2017). Tagetes erecta is a multipurpose plant having ornamental, medicinal, insecticidal, colorant, food, forage applications and enormous researches demonstrated its effect on plant diseases (Dunkel et al., 2010 and Devika and Justin, 2014).

This investigation aimed to control onion purple blotch, improve vegetative growth and onion bulb yield through foliar sprays with different concentrations of vermicompost tea and Tagetes erecta extract in comparison with Luna Experience fungicide.

\section{Materials and Methods}

Isolation and identification of the causal organism:

Onion plants showing typical symptoms of purple blotch disease were collected from a field located at Beheira governorate. Infected leaves were thoroughly washed with tap water, air dried, cut into small pieces, each piece contained single lesion, surface disinfected with sodium hypochlorite (5\% active chlorine) for 2 minutes, washed with sterilized distilled water and dried between two sterilized filter papers. Pieces were placed in Petri dishes containing water agar medium and incubated at $25 \pm 0.1^{\circ} \mathrm{C}$ for $3-5$ days. Hyphal tip or single spore technique (Riker and Riker, 1936) were used to purify the growing fungal isolates on potato dextrose agar medium (PDA). The isolated fungi were identified according to their cultural, morphological and microscopical characteristics as described by Woudenberg et al. (2014). The isolates were kept in PDA slants at $4^{\circ} \mathrm{C}$ for further studies.

\section{Vermicompost tea:}

Vermicompost tea (VCT) was obtained from Central Laboratory for Agricultural Climate, ARC, Giza, Egypt. Vermicompost was mixed with tap water as 1:10 (w/v) in $19 \mathrm{~L}$ plastic bucket. The mixture was left open for 7 days at $20-21^{\circ} \mathrm{C}$ and stirred once on the fourth day after preparation. The resulted VCT was filtered through a nylon membrane and stored at $4^{\circ} \mathrm{C}$ for further use (Weltzien, 1991).

Tagetes erecta extract (TE):

Extracts of Tagetes erecta plants (marigold), collected by steam system were purchased from KATO Aromatic Co., Giza, Egypt.

Egypt. J. Phytopathol., Vol. 47, No. 1 (2019) 


\section{Luna Experience:}

The fungicide Luna Experience SC, consists of Fluopyram $17.6 \%$ and Tebuconazole 17.6\%, is recommended against onion purple blotch by the Approved Recommendations to Control Agricultural Pests, Agricultural Pesticides Committee, Ministry of Agriculture, Egypt (2015) was used in this investigation for comparison with the other tested treatments. The fungicide is manufactured by Bayer, Crop Science, Germany.

Effect of Tagetes erecta extract on linear growth of Alternaria porri:

Each liter of fusible autoclaved PDA medium was amended with any of 0.25 , $0.5,1.0,2.0$ and $3.0 \mathrm{ml}$ TE extract and $0.05 \%$ tween 20 and gently homogenated. The whole mixture was poured just before solidification in $9 \mathrm{~cm}$ Petri dishes at the rate of $10 \mathrm{cc}$ for each. Periphery fungal discs $(5 \mathrm{~mm})$ of 7 days old Alernaria porri culture were used to inoculate the center of each plate after medium solidification. Five plates were used as replicates for each concentration and the control (untreated medium). The plates were incubated at $25 \pm 0.1^{\circ} \mathrm{C}$ till mycelial growth covered the medium surface in any plate. Reduction in linear growth was calculated according to the following formula:

$$
\text { Reduction of linear growth }(\%)=\frac{\text { Treatment }- \text { control }}{\text { Control }} \times 100
$$

\section{Field application:}

Field experiments were carried out during 2015/2016 and 2016/2017 seasons at Etay El-Baroud, Agricultural Research Station, Beheira governorate, Egypt. Experiments were designed as complete randomized blocks. Four plots were used as replicates for each treatment and control. The area for each plot was $10.5 \mathrm{~m}^{2}(3.0 \times$ $3.5 \mathrm{~m}$ ). Italy red and Giza $20 \mathrm{cvs}$. onion transplants of sixty days old were transplanted on 15 of November. All treatments received the same recommended agricultural practices until harvest in May. VCT was used at the concentrations of 12.5 and $25 \mathrm{ml} / \mathrm{L}$, while TE extract was used at the concentrations of 2 and $3 \mathrm{ml} / \mathrm{L}$, while Luna Experience fungicide was used at the rate of $1 \mathrm{ml} / \mathrm{L}$. Super Film at 0.5 $\mathrm{ml} / \mathrm{L}$ was used as spreader and adhesive material. Foliar sprays of all treatments were applied every other week starting from January $15^{\text {th }}$ until April $15^{\text {th }}$, as seven foliar sprays.

\section{Chlorophyll contents:}

Chlorophyll (Chl.) a and b contents in onion leaves were determined at the end of April for both seasons according to Moran (1982). Absorbance was measured at 647 and $664 \mathrm{~nm}$ using spectrophotometer (Jenway 6105 UV-VIS), and the following equations were used for calculation:

$$
\begin{aligned}
& \text { Chl. } \mathrm{a}\left(\mu \mathrm{g} \mathrm{mL}^{-1}\right)=12.46 \mathrm{~A}_{664}-2.49 \mathrm{~A}_{647} \\
& \text { Chl. } \mathrm{b}\left(\mu \mathrm{g} \mathrm{mL}^{-1}\right)=5.6 \mathrm{~A}_{664}+23.26 \mathrm{~A}_{647}
\end{aligned}
$$


Peroxidase and polyphenoloxidase activity:

At the end of April, activity of peroxidase (POD) and polyphenoloxidase (PPO) as unit/mg protein was determined using spectrophotometer (UV-Vis $9100 \mathrm{~B}$, LabTech) as described by Hammer Schmidt et al. (1982) and Benjamin and Montgomery (1973) respectively.

Disease severity $(D S)$ and plant parameters:

After the last spray, representative twenty-five plants of such plot were randomly tagged for DS assessment using the scale described by Sharma (1986) and disease severity was determined according to Wheeler (1969) as follows:

Disease severity $(\%)=\frac{\text { Sum of all disease ratings }}{\text { Total no. of ratings } \times \text { maximum disease grade }} \times 100$

At the end of each season, number of leaves/plant, plant height $(\mathrm{cm})$ and onion bulb yield $(\mathrm{Kg} / \mathrm{plot})$ were determined.

Statistical analysis:

The obtained data were statistically analyzed and significance of differences among treatments was assessed by the least significant difference (LSD) at 5\% probability using SAS ANOVA program V.9 (Anonymous, 2014).

\section{Results and Discussion}

Isolation and identification of the causal organism:

The typical symptoms of purple blotch disease on onion plants were observed. Small, sunken, oval to eye shaped lesions were found with brown to purple color surrounded by a light brown area. In severe cases, blotches were enlarged up to 10 $\mathrm{cm}$ long and were covered with conidia. On agar media fluffy creamy white colony was noticed, changed to greenish grey and finally turned light olivaceous with distinct light green zonation with time. Mycelium is initially hyaline and becomes later pale brown to olivaceous brown. The hyphae are septate and irregularly branched. The conidiophores arise singly or in groups, cylindrical straight or flexuous pale to mid brown, septate and blunt at the tips. Conidia are solitary, straight or curved with the body of conidium ellipsoidal tapering to the beak and having 7 to 9 transverse septa and 1 to 3 longitudinal septa. With the mentioned characteristics, the isolated pathogen was identified as Alternaria porri (Ellis) Cif. according to Woudenberg et al. (2014).

Effect of T. erecta extract on linear growth of A. porri:

Effect of different concentrations of $T$. erecta extract to inhibit A. porri mycelium growth in vitro is demonstrated in Table (1). All tested concentrations reduced fungus linear growth. The reduction of fungal growth was increased with increasing the extract concentration. The most effective concentration was $3 \mathrm{ml} / \mathrm{L}$ followed by $2 \mathrm{ml} / \mathrm{L}$, caused 51.3 and $50.0 \%$ reduction in linear growth, respectively. This finding was also found by Shafique et al. (2011) who reported that aqueous

Egypt. J. Phytopathol., Vol. 47, No. 1 (2019) 
extract of $T$. erectus reduced the growth of Ascochyta rabiei by 55-73\%. Mehmood et al. (2014) also found that aqueous root, shoot and flower extracts of T. erectus suppressed the growth of Alternaria alternata by 90,44 and $57 \%$, respectively. Wavare et al. (2017) similarly reported that aqueous extract of $T$. erecta completely inhibited the growth of Sclerotium rolfsii at $1 \mathrm{ml} / 50 \mathrm{ml}$ liquid medium, while treated filter paper disks by $100 \mathrm{mg} / \mathrm{ml}$ gave $19.7 \mathrm{~mm}$ inhibition zone. The antagonistic effect of $T$ erecta may be due to presence of suppressive bioactive materials as distinguished by Devika and Justin (2014) who found 19 and 31 bioactive compounds in leaves and flowers of Tagetes, respectively, including Tetrad ecannoic acid, Hexadecanoic acid, 9,12 and15 Octadecatrienoic acid, Stigmasterol, Phytol and Celidoniol.

Table (1): Effect of Tagetes erecta extract on the linear growth of $A$. porri after incubation at $25 \pm 0.1^{\circ} \mathrm{C}$.

\begin{tabular}{cc}
\hline Concentration $(\mathrm{ml} / \mathrm{L})$ & Reduction in linear growth $(\%)$ \\
\hline 0.25 & 28.4 \\
0.50 & 35.2 \\
1.0 & 36.8 \\
2.0 & 50.0 \\
3.0 & 51.3 \\
Control (untreated) & 0.0 \\
\hline L.S.D at 0.05 & 1.0 \\
\hline
\end{tabular}

Effect of VCT and T. erecta extract on onion purple blotch in vivo:

Under field conditions, different concentrations of VCT and TE extract were used to study their effect on controlling onion purple blotch on Italy red and Giza 20 onion cvs. in comparison with Luna Experience fungicide. Data presented in Table (2) show that purple blotch severity on Giza 20 was more than on Italy red. All tested treatments significantly decreased disease severity compared with the control during the two growing seasons 2015/2016 and 2016/2017. Higher concentrations of VCT and TE caused lower purple blotch severity. TE extract was more effective than VCT and Luna Experience to control purple blotch, while Luna Experience was more effective than VCT. The highest reduction was achieved with TE at $3 \mathrm{ml} / \mathrm{L}$ followed by $2 \mathrm{ml} / \mathrm{L}$ concentration, which gave 66.2 and $61.3 \%$ efficacy on Italy red and 72.5 and $67.9 \%$ on Giza 20 in the two seasons, respectively.

The antifungal activity of Tagetes sp. (marigold) was also observed by Thembo et al. (2010) against certain mycotoxigenic fungi including Fusarium verticillioides, F. proliferatum, Aspergillus flavus and A. parasiticus. Nahak and Sahu (2017) found that the use of aqueous extract of marigold flowers on tomato plants reduced early blight, fusarium wilt, fruit spot, blossom end rot, sun scald by 61.53, 18.42, 27.41, 50.43 and $26.44 \%$, respectively, compared to the untreated tomato plants. The antifungal and antimicorbial properties of Tagetes species could be attributed to its 
content of aromatic compounds including monoterpene hydrocarbons such as ocimenes, limonene, terpinene, myrcene and in acyclic monoterpene ketones (tagetone, dihydrotagetone, and tagetenone), in addition to lower amounts of sesquiterpene hydrocarbons and oxygenated compounds (Salehi et al., 2018).

On the other hand, application of VCT resulted significant efficacy against purple blotch in onion comparing with the control treatment. These results are in harmony with numerous scientific reports shown up during the past two decades to reduce severity of several foliar diseases including apple scab, powdery mildew, and gray mold (Weltzien, 1991; Elad and Shteinberg, 1994 and Cronin et al., 1996). In field experiment, VCT reduced percentage of onion white rot (Amin et al., 2016). Edwards et al. (2006) reported that VCT produced from cattle waste vermicompost suppressed tomato Verticillium wilt significantly. Solid vermicompost also can suppress a range of plant pathogens such as Pythium sp. in radishes and Rhizoctonia in cucumbers. Low field application rates of vermicompost suppressed Verticillium wilt in strawberries, Phomopsis sp. and powdery mildew in grapes and bacterial rot in cucumbers. Foliar sprays with compost water extract significantly reduced the incidence of bacterial spot in tomato fruit. The inhibitory effect may back to antibiosis, competition, antibiotic metabolites and low molecular weight, heat stable, non-protein metabolite produced by micro-organisms during fermentation, (AlDahmani et al., 2003).

Table (2): Effect of vermicompost tea, Tagetes erecta extract and fungicide Luna Experience as foliar spray ${ }^{*}$ on disease severity of purple blotch on cvs. Italy red and Giza 20 onion plants under field conditions at Beheira governorate, during 2015/16 and 2016/17 growing seasons.

\begin{tabular}{lccccccccc}
\hline & & \multicolumn{7}{c}{ Disease severity } \\
\cline { 3 - 10 } Treatments & Conc. & \multicolumn{7}{c}{ Italy red cv. } \\
\cline { 3 - 10 } & $2015 / 16$ & $2016 / 17$ & Mean & $\begin{array}{c}\text { Efficacy } \\
(\%)^{* *}\end{array}$ & $2015 / 16$ & $2016 / 17$ & Mean & $\begin{array}{c}\text { Efficacy } \\
(\%) * *\end{array}$ \\
\hline \multirow{2}{*}{ VCT } & $12.5 \mathrm{ml} / \mathrm{L}$ & 14.0 & 12.5 & 13.3 & 43.6 & 15.3 & 14.2 & 14.7 & 55.4 \\
& $25 \mathrm{ml} / \mathrm{L}$ & 12.3 & 10.5 & 11.4 & 51.4 & 13.7 & 12.8 & 13.3 & 59.9 \\
\cline { 2 - 10 } TE & $2 \mathrm{ml} / \mathrm{L}$ & 9.7 & 8.5 & 9.1 & 61.3 & 11.0 & 10.2 & 10.6 & 67.9 \\
\multirow{2}{*}{ Luna } & $3 \mathrm{ml} / \mathrm{L}$ & 8.3 & 7.6 & 8.0 & 66.2 & 9.3 & 8.8 & 9.1 & 72.5 \\
\cline { 2 - 10 } Control & $1 \mathrm{ml} / \mathrm{L}$ & 10.3 & 9.2 & 9.8 & 58.5 & 11.7 & 10.7 & 11.2 & 66.2 \\
\hline & & 26.0 & 21.0 & 23.5 & - & 34.3 & 31.7 & 33.0 & - \\
\hline \multicolumn{2}{l}{ LSD at 0.05} & 2.8 & 1.1 & - & - & 1.4 & 1.5 & - & - \\
\hline
\end{tabular}

* Spray every two weeks beginning from January $15^{\text {th }}$ to April $15^{\text {th }}$ (Seven sprays)

$$
* * \text { Efficacy }(\%)=\frac{\text { Control-treatment }}{\text { Control }} \times 100
$$

Egypt. J. Phytopathol., Vol. 47, No. 1 (2019) 
Effect of VCT and T. erecta extract on some agronomic onion characteristics and onion bulb yield:

Data presented in Table (3) show that all treatments increased number of leaves, plant height and onion bulb yield of Italy red and Giza 20 onion cultivars in both successive seasons compared to untreated plants. Increased concentration of such treatment caused a positive increase of the tested agronomic characteristic values. Significant differences between the tested treatments and the control regarding number of leaves was not consistent across the growing seasons and onion cultivars. Luna Experience fungicide increased plant height more than other treatments and control. Luna Experience at the recommended dose and VCT at $25 \mathrm{ml} / \mathrm{L}$. followed by $\mathrm{TE}$ extract at $3 \mathrm{ml} / \mathrm{L}$ significantly resulted in the highest bulb yield. This increment in yield could be attributed to the control of purple blotch disease as well as greater leaf number and plant height.

Plant height of Italy red onion cv. was the highest when plants were sprayed with $\mathrm{TE}$ at $3 \mathrm{ml} / \mathrm{L}$ where it gave 68.5 and $69.5 \mathrm{~cm}$ in both successive seasons, while VCT at $25 \mathrm{ml} / \mathrm{L}$ was the most effective treatment on Giza 20 onion cv. with 76.5 and 75.8 $\mathrm{cm}$, respectively without significant differences with Luna experience treatment.

Table (3): Effect of vermicompost tea, Tagetes erecta extract and fungicide Luna Experience as foliar spray* on some agronomic characteristics on cvs. Italy red and Giza 20 onion plants under field conditions at Beheira governorate, during 2015/16 and 2016/17 growing seasons.

\begin{tabular}{|c|c|c|c|c|c|c|c|c|}
\hline \multirow{3}{*}{ Cultivars } & \multirow{3}{*}{ Treatments } & \multirow{3}{*}{ Concentrations } & \multicolumn{6}{|c|}{ Some agronomic characteristics of onion plants } \\
\hline & & & \multicolumn{2}{|c|}{$\begin{array}{c}\text { No. of } \\
\text { leaves/plant }\end{array}$} & \multicolumn{2}{|c|}{$\begin{array}{l}\text { Plant height } \\
(\mathrm{cm})\end{array}$} & \multicolumn{2}{|c|}{$\begin{array}{c}\text { Onion yield } \\
(\mathrm{kg} / \mathrm{plot})\end{array}$} \\
\hline & & & $2015 / 16$ & $2016 / 17$ & $2015 / 16$ & $2016 / 17$ & $2015 / 16$ & $2016 / 17$ \\
\hline \multirow{6}{*}{ Italy red } & \multirow{2}{*}{ VCT } & $12.5 \mathrm{ml} / \mathrm{L}$ & 11.4 & 11.8 & 59.5 & 60.0 & 46.9 & 48.2 \\
\hline & & $25 \mathrm{ml} / \mathrm{L}$ & 11.6 & 12.2 & 60.5 & 62.0 & 49.6 & 50.4 \\
\hline & \multirow{2}{*}{ TE } & $2 \mathrm{ml} / \mathrm{L}$ & 11.0 & 11.6 & 60.8 & 64.8 & 46.4 & 46.8 \\
\hline & & $3 \mathrm{ml} / \mathrm{L}$ & 11.6 & 12.2 & 68.5 & 67.3 & 48.4 & 49.2 \\
\hline & Luna & $1 \mathrm{ml} / \mathrm{L}$ & 11.8 & 12.6 & 68.8 & 69.5 & 49.8 & 51.2 \\
\hline & Control & - & 10.4 & 11.0 & 57.8 & 59.8 & 42.7 & 44.2 \\
\hline L.S.D. at & & & 2.2 & 1.1 & 5.8 & 4.8 & 1.4 & 1.7 \\
\hline \multirow{6}{*}{ Giza 20} & \multirow{2}{*}{ VCT } & $12.5 \mathrm{ml} / \mathrm{L}$ & 12.4 & 11.4 & 74.0 & 75.3 & 45.5 & 46.3 \\
\hline & & $25 \mathrm{ml} / \mathrm{L}$ & 11.4 & 11.8 & 76.5 & 75.8 & 47.9 & 47.3 \\
\hline & \multirow{2}{*}{ TE } & $2 \mathrm{ml} / \mathrm{L}$ & 11.0 & 11.6 & 71.3 & 72.3 & 44.4 & 45.0 \\
\hline & & $3 \mathrm{ml} / \mathrm{L}$ & 11.8 & 12.0 & 72.0 & 70.8 & 47.5 & 47.0 \\
\hline & Luna & $1 \mathrm{ml} / \mathrm{L}$ & 12.6 & 12.0 & 76.8 & 76.3 & 48.6 & 49.1 \\
\hline & Control & - & 10.8 & 10.6 & 64.0 & 64.8 & 43.5 & 42.4 \\
\hline \multicolumn{3}{|c|}{ LSD at 0.05} & 2.7 & 2.0 & 5.3 & 3.7 & 1.1 & 1.1 \\
\hline
\end{tabular}

* Spray every two weeks beginning from January $15^{\text {th }}$ to April $15^{\text {th }}$ (Seven sprays) 
Similar findings were obtained by Nahak and Sahu (2017) who found that foliage application of tomato plants by $T$. patula aqueous extract increased shoot lengths (75.87\%), branches (27.42\%), leaf numbers (17\%), bud numbers $(42.71 \%)$, flower numbers $(54.96 \%)$ and fruit numbers $(66.21 \%)$ compared to untreated. The promotive effect could be due to flavonoids patuletin, quercetagetin, carotenoid lutein and quercetin and their derivatives which act as a strong anti-oxidative and cyto-protective (Hooks et al., 2010). On the other hand, VCT treatment at the rate of $15 \mathrm{~L} /$ fed. four times with irrigation water increased onion bulb yield, plant height, no. of leaves/plant, onion fresh and dry weight (Amin et al., 2016). Also, values of growth, flowering, and yield of tomato, cucumber, and other crops were increased as response for VCT treatment (Mistry and Mukherjee, 2015). Pant et al. (2009) stated that use of VCT increased the above-ground fresh and dry weights, leaf area and extractable mineral element concentration in pak choi tissue. Keeling et al. (2003) reported that applying VCT to oilseed rape plants at the initial stage of growth increased both root development and plant growth. The plant responses may be due to the plant growth regulators such as indole acetic acid, kinetin, or gibberellins associated with humic and fulvic acids (Mistry and Mukherjee, 2015) which extracted or produced by microorganisms. Improved root growth or nutrient uptake per unit by root might be one of the mechanisms involved in stimulating plant growth. Soluble and available nutrients during composting, enhancing beneficial microbial communities especially plant growth promoting rhizobacteria (Allison and Janice, 2006 and Pant et al., 2009).

Effect of VCT and TE extract on leaves chlorophyll of onion plants:

Onion leaves contents of chlorophyll a and $b$ were increased with spraying either of all tested treatments compared to the control plants as shown in Table (4). Chlorophyll contents were increased with increasing of treatment concentrations. VCT foliar sprays particularly at $25 \mathrm{ml} / \mathrm{L}$ increased chlorophyll a and b contents in $\mathrm{cv}$. Italy red onion plants more than other treatments in both seasons, while TE at the rate of $3 \mathrm{ml} / \mathrm{L}$ followed by $\mathrm{VCT}$ at $25 \mathrm{ml} / \mathrm{L}$ were the most effective treatments to increase chlorophyll a and b contents in cv. Giza 20 onion leaves.

Sundraraju and Kiruthika (2009) found that Tagetes extract was one of the best treatments for increasing chlorophyll contents in banana leaves. The increased chlorophyll content due to the application of vermicompost in lettuce was recorded by Ali et al. (2007). Increase of chlorophyll contents was due to the presence of microorganisms in the vermicompost, which colonize in the rhizosphere and stimulate the plant growth and biochemical content. Subler et al. (1998) mentioned that increase in chlorophyll content in response to vermicompost was observed at early stages of marigold. Topical sprays with salicylic acid had the same effect, which led them to propose the probability of induced systemic resistance by compost water extract via the same mechanism. Also, Vijayalakshmi and Karthiyayini (2018) found that treatment of Solanum nigrum and Trigonella foenum-

Egypt. J. Phytopathol., Vol. 47, No. 1 (2019) 
graecum seedlings with vermicompost alone or combined with Azospirillum increased chlorophyll, protein, carbohydrates and amino acid content.

Table (4): Effect of vermicompost tea, Tagetes erecta extract and fungicide Luna Experience as foliar spray ${ }^{*}$ on chlorophyll content ${ }^{* *}$ in cvs. Italy red and Giza 20 onion plants grown under field conditions at Beheira governorate, during $2015 / 16$ and $2016 / 17$ growing seasons.

\begin{tabular}{|c|c|c|c|c|c|c|}
\hline \multirow[t]{2}{*}{ Cultivars } & \multirow[t]{2}{*}{ Treatments } & \multirow[t]{2}{*}{ Concentrations } & \multicolumn{2}{|c|}{$\begin{array}{l}\text { Chlorophyll A } \\
\left(\mu \mathrm{gLL}^{-1}\right)\end{array}$} & \multicolumn{2}{|c|}{$\begin{array}{l}\text { Chlorophyll B } \\
\left(\mu \mathrm{g} \mathrm{mL}^{-1}\right)\end{array}$} \\
\hline & & & $2015 / 16$ & $2016 / 17$ & $2015 / 16$ & $2016 / 17$ \\
\hline \multirow{6}{*}{ Italy red } & \multirow{2}{*}{ VCT } & $12.5 \mathrm{ml} / \mathrm{L}$ & 2.43 & 2.40 & 3.59 & 3.30 \\
\hline & & $25 \mathrm{ml} / \mathrm{L}$ & 3.95 & 3.70 & 3.63 & 3.50 \\
\hline & \multirow{2}{*}{$\mathrm{TE}$} & $2 \mathrm{ml} / \mathrm{L}$ & 2.29 & 2.17 & 2.73 & 2.47 \\
\hline & & $3 \mathrm{ml} / \mathrm{L}$ & 2.65 & 2.63 & 3.06 & 2.93 \\
\hline & Luna & $1 \mathrm{ml} / \mathrm{L}$ & 2.82 & 2.70 & 1.69 & 1.50 \\
\hline & Control & & 2.52 & 2.50 & 2.79 & 2.33 \\
\hline L.S.D. at & & & 0.53 & 0.39 & 0.29 & 0.36 \\
\hline \multirow{6}{*}{ Giza 20} & \multirow{2}{*}{ VCT } & $12.5 \mathrm{ml} / \mathrm{L}$ & 2.72 & 2.80 & 2.51 & 2.68 \\
\hline & & $25 \mathrm{ml} / \mathrm{L}$ & 2.78 & 2.87 & 2.84 & 2.88 \\
\hline & \multirow{2}{*}{$\mathrm{TE}$} & $2 \mathrm{ml} / \mathrm{L}$ & 2.45 & 2.60 & 2.55 & 2.70 \\
\hline & & $3 \mathrm{ml} / \mathrm{L}$ & 2.98 & 3.10 & 2.98 & 3.10 \\
\hline & Luna & $1 \mathrm{ml} / \mathrm{L}$ & 1.83 & 1.80 & 2.88 & 2.97 \\
\hline & Control & & 2.41 & 2.43 & 2.33 & 2.27 \\
\hline \multicolumn{3}{|c|}{ LSD at 0.05} & 0.32 & 0.25 & 0.38 & 0.34 \\
\hline
\end{tabular}

* Spray every two weeks beginning from January $15^{\text {th }}$ to April $15^{\text {th }}$ (Seven sprays)

${ }^{* *}$ Estimated at the end of April for each season (five months after transplantation)

The activity of both peroxidase and polyphenoloxidase in the two tested onion cultivars during the two seasons was affected by most of the tested treatments compared to untreated plants as shown in Table (5). In all treatments, increase of VCT and TE extract concentrations led to increase of PO and PPO activity. Also, all treatments increased the activity of the tested enzymes more than Luna Experience except PPO on cv. Giza 20 at the second growing season with TE at the rate of 2 $\mathrm{ml} / \mathrm{L}$. VCT at $25 \mathrm{ml} / \mathrm{L}$ was the best treatment to enhance PO and PPO activity for both onion cultivars during both seasons.

These results in agreement with Goel et al. (2015) who found that aqueous extract from $T$. erecta leaves stimulated the activity of PO, PPO, lipoxygenase and catalase in tomato as induced defense enzymes. Also, activity of PO and PPO was increased in the tested plants as a response to $T$. erecta treatment (Sundraraju and Kiruthika, 2009). Regarding VCT effects, Zhang et al. (1998) demonstrated that compost tea applied to the foliage of Arabidopsis plants stimulated 1,3-glucanase 
activity. Increases in total phenols, protein, carbohydrates and amino acids were also recorded in plants treated by vermicompost extracts according to Pant et al. (2009).

Table (5): Effect of vermicompost tea, Tagetes erecta extract and fungicide Luna Experience as foliar spray ${ }^{*}$ on peroxidase and polyphenoloxidase activity** on cvs. Italy red and Giza 20 onion plants grown under field conditions at Beheira governorate, during 2015/16 and 2016/17 growing seasons.

\begin{tabular}{|c|c|c|c|c|c|c|}
\hline \multirow{3}{*}{ Cultivars } & \multirow{3}{*}{ Treatments } & \multirow{3}{*}{ Concentrations } & \multicolumn{4}{|c|}{ Enzymatic activity (unit/mg protein) } \\
\hline & & & \multicolumn{2}{|c|}{ Peroxidase } & \multicolumn{2}{|c|}{ Polyphenoloxidase } \\
\hline & & & $2015 / 16$ & $2016 / 17$ & $2015 / 16$ & $2016 / 17$ \\
\hline \multirow{6}{*}{ Italy red } & \multirow{2}{*}{ VCT } & $12.5 \mathrm{ml} / \mathrm{L}$ & 6.13 & 5.27 & 2.74 & 2.50 \\
\hline & & $25 \mathrm{ml} / \mathrm{L}$ & 6.69 & 6.07 & 3.01 & 3.09 \\
\hline & \multirow{2}{*}{$\mathrm{TE}$} & $2 \mathrm{ml} / \mathrm{L}$ & 6.30 & 5.23 & 2.67 & 2.27 \\
\hline & & $3 \mathrm{ml} / \mathrm{L}$ & 6.82 & 5.87 & 2.74 & 2.53 \\
\hline & Luna & $1 \mathrm{ml} / \mathrm{L}$ & 4.23 & 4.20 & 2.09 & 2.00 \\
\hline & Control & - & 5.43 & 4.67 & 2.73 & 2.67 \\
\hline \multicolumn{2}{|c|}{ L.S.D. at $5 \%$} & & 1.43 & 0.39 & 0.46 & 0.36 \\
\hline \multirow{6}{*}{ Giza 20} & \multirow{2}{*}{ VCT } & $12.5 \mathrm{ml} / \mathrm{L}$ & 5.65 & 5.70 & 2.42 & 2.50 \\
\hline & & $25 \mathrm{ml} / \mathrm{L}$ & 5.87 & 5.97 & 2.65 & 2.73 \\
\hline & \multirow{2}{*}{ TE } & $2 \mathrm{ml} / \mathrm{L}$ & 5.10 & 5.23 & 2.04 & 1.72 \\
\hline & & $3 \mathrm{ml} / \mathrm{L}$ & 5.13 & 5.30 & 2.08 & 2.20 \\
\hline & Luna & $1 \mathrm{ml} / \mathrm{L}$ & 4.08 & 4.03 & 1.66 & 1.80 \\
\hline & Control & - & 4.23 & 3.83 & 1.87 & 1.73 \\
\hline \multicolumn{2}{|c|}{ LSD at 0.05} & & 0.78 & 0.53 & 0.55 & 0.45 \\
\hline
\end{tabular}

* Spray every two weeks beginning from January $15^{\text {th }}$ to April $15^{\text {th }}$ (Seven sprays)

** Estimated at the end of April for each season (five months after transplantation)

Based on the previous results, it is possible to recommend cross-spraying between VCT at $25 \mathrm{ml} / \mathrm{L}$ with TE at $3 \mathrm{ml} / \mathrm{L}$, until a future study clarify the best possible treatment regime that could be used effectively.

\section{$R$ ef e r e n c e $s$}

Abdel-Rahim, I.R.; Abdel-Hafez, S.I.I. and Abo-Elyousr, K.A.M. 2016. Purple blotch disease of onion plant (Allium cepa L.) in Assiut, Egypt. LAP Lambert Academic Publishing, 192 pp.

Al-Dahmani, J.H.; Abbasi, P.A.; Miller, S.A. and Hoitink, H.A.J. 2003. Suppression of bacterial spot of tomato with foliar sprays of compost extracts under greenhouse and field conditions. Plant Disease. 87: 913-919.

Egypt. J. Phytopathol., Vol. 47, No. 1 (2019) 
Ali, M.; Griffiths, A.J.; Williams, K.P. and Jonesm, D.L. 2007. Evaluating growth characteristic of lettuce in vermicompost and green waste compost. European Journal of Soil Biology. 43: 316-319.

Allison, L.H.J and Janice, E.T. 2006. Compost and vermicompost as amendments promoting soil health, pp: 453-466, In: Uphoff, N; Ball, A.S.; Fernandes, E.; Herren, H.; Husson, O.; Laing, M.; Palm, C.; Pretty, J.; Sanchez, P.; Sanginga, N. and Thies, J. 2006. Biological approaches to sustainable soil systems, $1^{\text {st }}$ Edition. CRC Press, PP 785.

Amin, M.M.; Fawaz, S.B.M. and Shalaby, S.I.M. 2016. Suppression effect of vermicompost tea on onion white rot. Assiut Journal of Agricultural Sciences. 47 (6): 87-99.

Anonymous, 2014. "Statistical Analysis System”. SAS User's Guide: Statistics. SAS Institute Inc. Editors, Cary, NC, 27513, USA.

Benjamin, N. and Montgomery, M.W. 1973. Polyphenoloxidase of royal ann cherries: Purification and characterization. Journal of Food Science. 38: 799806.

Cramer, C.S. 2000. Breeding and genetics of Fusarium basal rot resistance in onion. Euphytica. 115: 159-166.

Cronin, M.J.; Yohalem, D.S.; Harris, R.F. and Andrews, J.H. 1996. Putative mechanism and dynamics of inhibition of the apple scab pathogen Venturia inaequalis by compost extracts. Soil Biology and Biochemistry. 28: 1241-1249.

Devika, R. and Justin, K. 2014. Screening and evaluation of bioactive components of Tagetes erecta L. by GC-MS analysis. Asian Journal of Pharmaceutical and Clinical Research. 7(2): 58-60.

Dunkel, F.V.; Jaronski, S.T.; Sedlak, C.W.; Meiler, S.U. and Veo, K.D. 2010. Effects of steam-distilled shoot extract of Tagetes minuta (Asterales: Asteraceae) and entomopathogenic fungi on larval Tetanops myopaeformis. Environmental Entomology. 39: 979-988.

Edwards, C.A. and Arancon, N.Q. 2004. The use of earthworms in the breakdown of organic wastes to produce vermicomposts and animal feed protein. In: Edwards, C.A. (Ed.), Earthworm Ecology, $2^{\text {nd }}$ CRC Press, Boca Raton, Fl; London; New York; Washington, pp. 345-438.

Edwards, C.A.; Arancon, N.Q. and Greytak, S. 2006. Effects of vermicompost teas on plant growth and diseases. BioCycle. 47(5): 28-31.

Elad, Y. and Shteinberg, D. 1994. Effect of compost water extracts on grey mold (Botrytis cinerea). Crop Protection. 13: 109-114. 
Goel, N.; Anukrati, K.; Singh, A. and Paul, P.K. 2015. Tagetes erecta leaf extract induces defense enzymes in Solanum lycopersicum. Journal of Chemical and Pharmaceutical Research. 7(7): 466-475.

Hammer Schmidt, R.; Nuckles, E.M. and Kuc, J. 1982. Association of enhanced peroxidase activity with induced systemic resistance of cucumber to Colletotrichum lagenarium. Physiologia Plantarum. 20: 73-82.

Hand, P.; Hayes, W.A.; Frankland, J.C. and Satchell, J.E. 1988. The vermicomposting of cow slurry. In: Earthworms in Waste and Environmental Management. The Hague: SPB Academic Publishing, Netherlands, pp. 49-63.

Hooks, C.R.R.; Wang, K.H.; Ploeg, A. and McSorley, R. 2010. Using marigold (Tagetes spp.) as a cover crop to protect crops from plant-parasitic nematodes. Applied Soil Ecology. 46: 307-320.

Ingham, E.R. 2005. The Compost Tea Brewing Manual, $5^{\text {th }}$ Edition. Soil Food Web, Inc., Corvallis. 79 pp.

Keeling, A.A.; McCallum, K.R. and Beckwith, C.P. 2003. Mature green waste compost enhances growth and nitrogen uptake in wheat (Triticum aestivum L.) and oilseed rape (Brassica napus L.) through the action of water-extractable factors. Bioresource Technology. 90: 127-132.

Mehmood, T.; Shafique, S.; Shafique, S. and Zaheer, Z. 2014. Fungitoxic potential of Tagetes erectus for the management of Alternaria alternata strains of tomato. Pakistan Journal of Botany. 46(3): 1047-1054.

Mistry, J. and Mukherjee, S. 2015. Vermicompost tea and its role in control of pest: A Review. International Journal of Advanced Research in Biological Sciences. 2(3): 111-113.

Moran, R. 1982. Formula for determination of chlorophyllous pigments extracted with N, N-Dimethylformamide. Plant Physiology. 69: 1376-1381.

Nahak, G. and Sahu, R.K, 2017. Bio-controlling effect of leaf extract of Tagetes patula L. (marigold) on growth parameters and diseases of tomato. Pakistan Journal of Biological Sciences. 20(1): 12-19.

Pant, A.P.; Radovich, T.J.K.; Hue, N.V.; Talcottb, S.T. and Krenek, K.A. 2009. Vermicompost extracts influence growth, mineral nutrients, phytonutrients and antioxidant activity in pak choi (Brassica rapa cv. Bonsai, Chinensis group) grown under vermicompost and chemical fertilizer, Journal of the Science of Food and Agriculture. 55: 3732-3741.

Riker, A.J. and Riker, R.S. 1936. Introduction to Research on Plant Diseases, St. Louis, Chicago, New York and Indianapolis, John's Swift Co., 117p.

Egypt. J. Phytopathol., Vol. 47, No. 1 (2019) 
Salehi, B.; Valussi, M.; Morais-Braga, M.F.B.; Carneiro, J.N.P.; Leal, A.L.A.B.; Coutinho, H.D.M.; Vitalini, S.; Kregiel, D.; Antolak, H.; Sharifi-Rad, M.; Silva, N.C.C.; Yousaf, Z.; Martorell, M.; Iriti, M.; Carradori, S. and Sharifi-Rad, J. 2018. Tagetes spp. Essential Oils and Other Extracts: Chemical characterization and biological activity. Molecules, 23(11): 2847. 35 pp.

Shafique, S.; Shafique, S.; Bajwa, R.; Akhtar, N. and hanif, S. 2011. Fungitoxic activity of aqueous and organic solvent extracts of Tagetes erectus on phytopathogenic fungus-Ascochyta rabiei. Pakistan Journal of Botany. 43(1): 59-64.

Sharma, S.R. 1986. Effect of fungicidal sprays on purple blotch and bulb yield of onion. Indian Phytopathology. 39(1): 78-82.

Subler, S.; Edwards, C.A. and Metzger, J. 1998. Comparing composts and vermicomposts. BioCycle. 39: 63-66.

Sundraraju, P. and Kiruthika, P. 2009. Effect of bio-control agent, Paecilomyces lilacinus along with neemcake and botanicals for the management of Meloidogyne incognita on banana. Indian Journal of Nematology. 39(2): 201206.

Surviliene, E.; Valiuskaitè, A. and Raudonis, L. 2008. The effect of fungicides on the development of downy mildew of onions. Zemdirbyste Agriculture. 95(3): 171-179.

Thembo, K.M.; Vismer, H.F.; Nyazema, N.Z.; Gelderblom, W.C. and Katerere, D.R. 2010. Antifungal activity of four weedy plant extracts against selected mycotoxigenic fungi. Journal of Applied Microbiology. 109: 1479-1486.

Vijayalakshmi, A. and Karthiyayini, R. 2018. Effect of vermicompost on biochemical content of two Indian green leafy vegetables. International Journal of Pharmaceutical Sciences and Research. 9(10): 4446-4450.

Wavare, S.H.; Gade, R.M. and Shitole, A.V. 2017. Effect of plant extracts, bio agents and fungicides against Sclerotium rolfsii causing collar rot in chickpea. Indian Journal of Pharmaceutical Sciences. 79(4): 513-520.

Weltzien H.C. 1991. Biocontrol of Foliar Fungal Diseases with Compost Extracts. In: Andrews, J.H. and Hirano, S.S. (eds) Microbial Ecology of Leaves. Brock/Springer Series in Contemporary Bioscience. Springer, New York, NY. PP 499.

Wheeler, B.E. 1969. An Introduction to Plant Diseases. John Wiley and Sons Ltd., London, UK. 374 pp. 
Woudenberg, J.H.C.; Truter, M.; Groenewald, J.Z.; and Crous, P.W. 2014. Largespored Alternaria pathogens in section Porri disentangled. Studies in Mycology. 79: 1-47.

Yardim, E.N.; Arancon, N.Q.; Edwards, C.A.; Oliver, T.J. and Byrne, R.J. 2006. Suppression of tomato hornworm (Manduca quinquemaculata) and cucumber beetles (Acalymma vittatum and Diabotrica undecimpunctata) populations and damage by vermicomposts. Pedobiologia. 50: 23-29.

Zhang, W.; Han, D.Y.; Dick, W.A.; Davis, K.R. and Hoitink, H.A.J. 1998. Compost and compost water extract-induced systemic acquired resistance in cucumber and Arabidopsis. Phytopathology. 88: 450-455.

Corresponding author: Amin, M.M.

E-mail: mmamesbah@gmail.com

(Received 21/04/2019;

in revised form 05/05/2019)

Egypt. J. Phytopathol., Vol. 47, No. 1 (2019) 


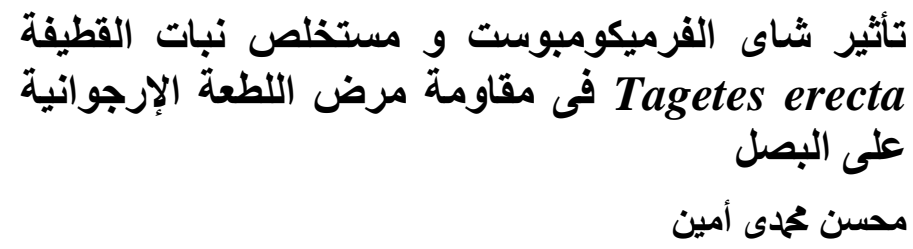

معهد بحوث أمراض النباتات ، مركز البحوث الزراعية ، الجيزة ، مصر

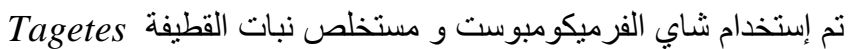
erecta

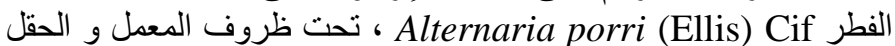

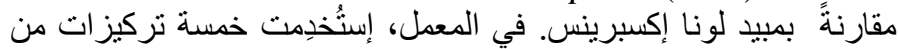

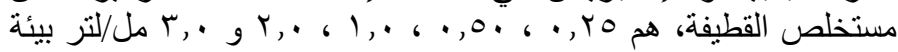

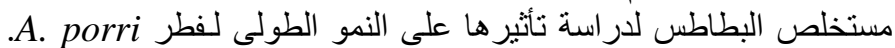

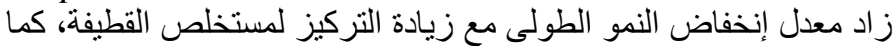

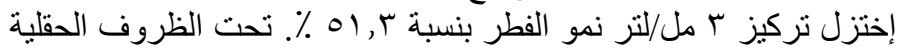

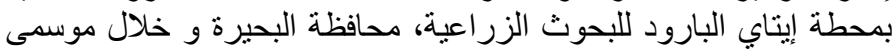

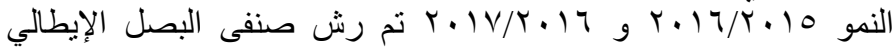

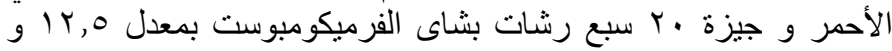

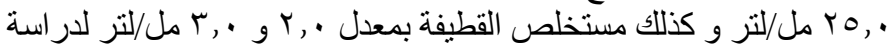

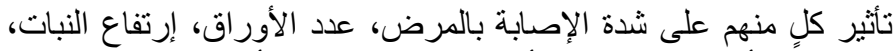

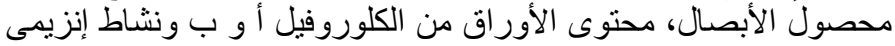

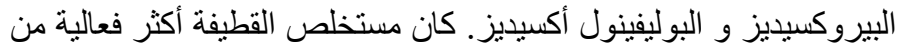

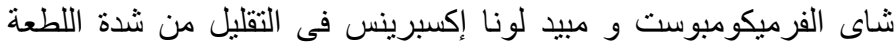

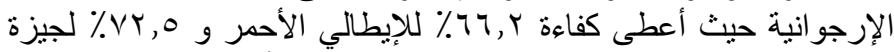

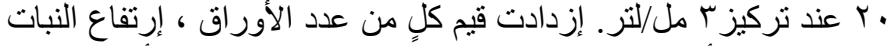

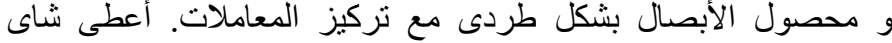

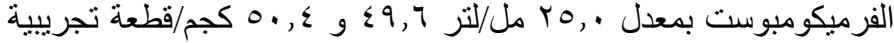

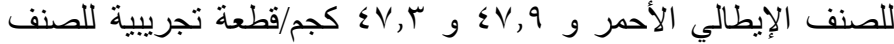

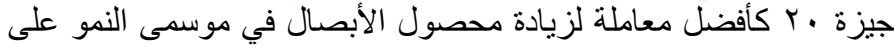

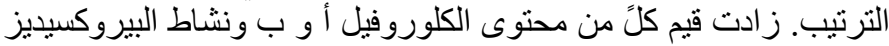
و البوليفينول أكسيديز في النباتات المعندئ. 